\title{
OVERWEIGHT AND OBESITY PREVALENCE IN SCHOOLCHILDREN AND EVALUATION OF THEIR HEALTHY NUTRITION KNOWLEDGE
}

\author{
Alexandrova A., P. Gatseva, R. Vasileva \\ Department of Hygiene, Ecomedicine, Professional Diseases and Toxicology, \\ Medical University - Plovdiv
}

Reviewed by: Assoc. Prof. V. Iotova

\begin{abstract}
Objective: The aim of this study was to evaluate overweight and obesity prevalence and healthy nutrition knowledge in adolescents aged 11-14 years, living in the town of Parvomai in district of Plovdiv. Material and methods: The overweight and obesity prevalence was assessed according to the international cut off points for body mass index for overweight and obesity proposed by Cole et al, 2000. A questionnaire of V.Duleva, 2005 was used for evaluation of healthy nutrition knowledge. Results: The results show that $20 \%$ of the studied boys and $12 \%$ of the girls are with overweight and obesity. The questionnaire's data show that a considerable part of the adolescents have not good information about healthy nutrition. Conclusion: Recommendations about elaboration of adequate educational programs for nutrition in the schools were made. The aim of this strategy is the development of healthy nutritional behavior in adolescents..
\end{abstract}

Key words: overweight, obesity, adolescent, nutrition, education

\section{INTRODUCTION}

Incidence of overweight among Bulgarian children increases in the last 20 years. Epidemiological studies all over the world and in Bulgaria reveal connection between imbalance nutrition, overweight in growing up and numerous diseases - arterial hypertension, diabetes mellitus, metabolic syndrome, cardiovascular diseases $(1,2,3,4,5,6,8,9,14,16,17)$. The problem "obesity" is an object of observation in early life because in $70-80 \%$ of the cases it begins in childhood (19). Obesity rate ranges from 5 to $30 \%$ and represents a complex medico-hygienic, social and psychological problem $(3,15)$. The necessity from information and knowledge about healthy nutrition as prevention medical strategy was underlined in these studies $(6,7,13,19)$.

The aim of this study is to estimate incidence of overweight and obesity among schoolchildren aged 11-14 years and to evaluate their healthy nutrition knowledge.

\section{MATERIAL AND METHODS}

Subjects of study were 100 schoolchildren ( 50 boys and 50 girls) aged 11-14 years living in the town of Parvomai in

Address for correspondence:

A.Alexandrova, Dept. of Hygiene and Ecomedicine

Medical University -Plovdiv, Vassil Aprilov Str.15A

4002 Plovdiv district of Plovdiv. The body mass index of the children was determined measuring the morphological indices weight and height (20). WHO-criteria, 2007 were used for the evaluation of the weight of children aged 7-19 years (12). The overweight and obesity prevalence was assessed according to the international cut off points for body mass index for overweight and obesity proposed by Cole et al, 2000 (11). A questionnaire of V.Duleva, 2005 (7) for assessment of schoolchildren's knowledge about nutrition was used. It included questions concerning schoolchildren's information about healthy nutrition and possible association of the nutrition with numerous diseases. SPSS for Windows was used for the statistical analysis of data. The possible association between overweight and obesity frequency in adolescents and their nutritional knowledge was estimated by means of relative risk (RR with $95 \%$ confidence interval).

\section{RESULTS AND DISCUSSION}

The mean age of the boys, included in the study was 11,78 $\pm 1,75$ years and of the girls - $12,04 \pm 1,11$ years without statistically significant differences between both genders $(\mathrm{t}=1,192, \mathrm{P}=0,2360)$. The results from the measurement and comparison of the body mass index with WHO-criteria, 2007 (12) indicated that $79 \%$ of the schoolchildren ( $78 \%$ of the boys and $80 \%$ of the girls ) were with normal body weight. $5 \%$ of the children ( $2 \%$ of the boys and $8 \%$ of 
the girls) were underweight. $16 \%$ of the studied children ( $20 \%$ of the boys and $12 \%$ of the girls) were with obesity and overweight and they are at health risk according to the criteria of WHO,1995 (20). Between relative parts of boys and girls with overweight and obesity were not found statistically significant differences $/ \mathrm{P}>0,05$ / (fig. 1 ) overweight and obesity were not found statistically significant differences $/ \mathrm{P}>0,05 /$ (fig.1).

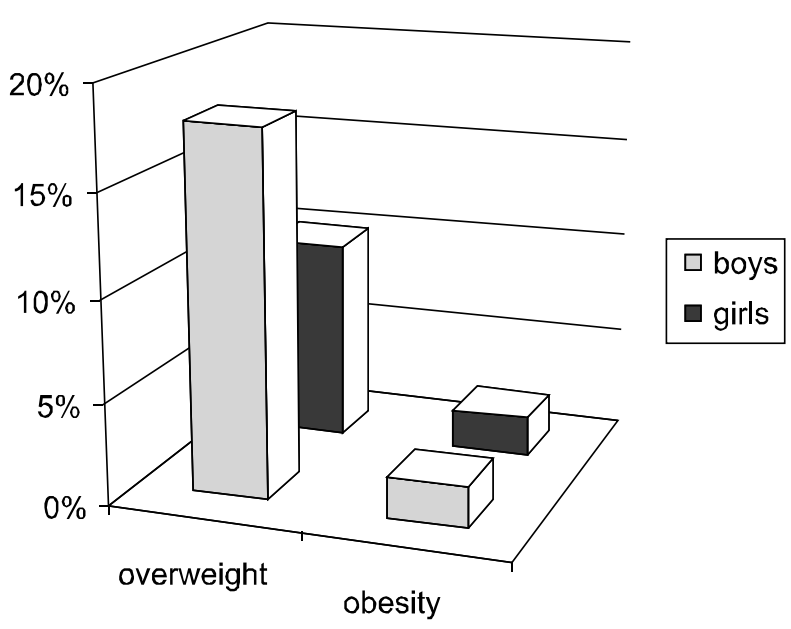

Fig.1

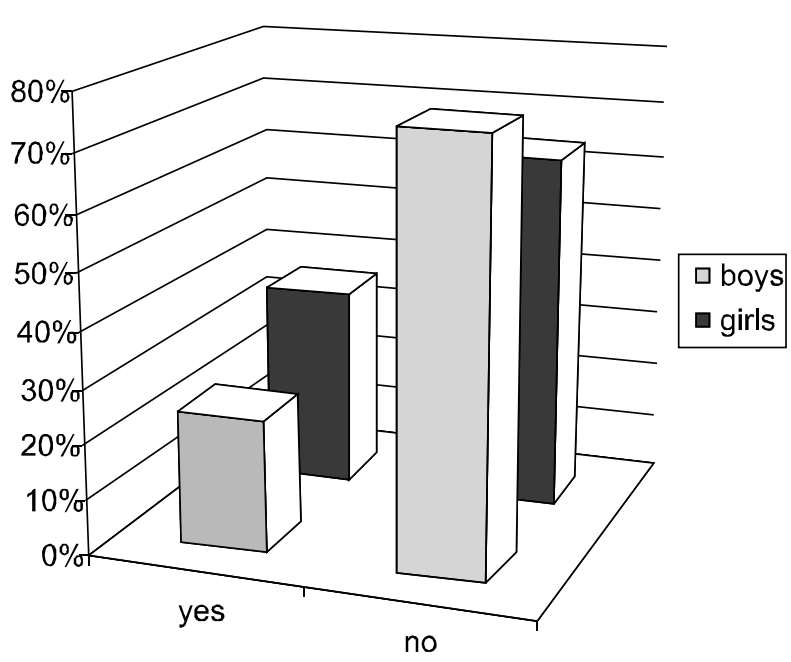

Fig. 2

The creating of healthful nutritional model in the early stages of the life can reduce the risk for the development of numerous diseases - diabetes mellitus, arterial hypertension, osteoporosis et al. $(10,16,17,18)$. The association between overweight in young people and increased morbidity and mortality in subsequent age is demonstrated in numerous epidemiological studies $(14,18)$. Considerable evidences confirm the great longtime health risk by the presence of overweight and obesity in childhood $(13,16)$. The maintaining of healthful nutrition habits and physical activity constitute fundamental premise for prevention of obesity (19).

The education of the children on the problems of the healthy nutrition influenced positively their knowledge about nutri- tional behavior and eating pattern. In this relation the schoolchildren were requested to answer questions concerning their information about healthy nutrition. Table 1 represents the positive answers of the questions assessing the schoolchildren's nutritional knowledge: $86 \%$ of the boys and $96 \%$ of the girls answered correctly on the question " Is varied nutrition necessary?". On the question " Do you think that the salty foods are healthy?" $76 \%$ of the boys and $64 \%$ of the girls gave negative answers. These results are indicator for good information about healthy nutrition (fig.2).

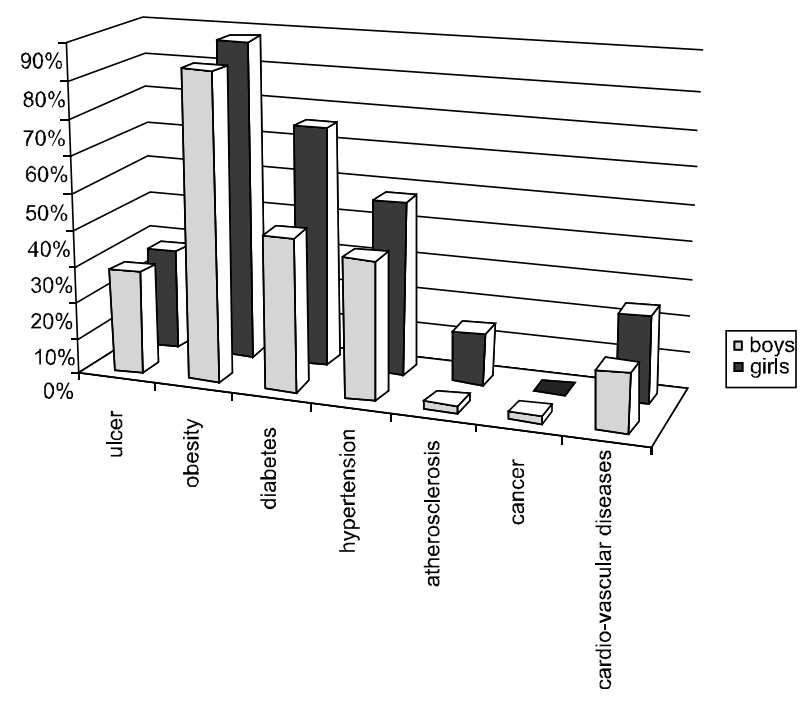

Fig. 3

Figure 3 presents the relative part of positive answers of schoolchildren about the relation between the nutrition and some diseases: $84 \%$ of the boys and $88 \%$ of the girls made a connection between the nutrition and the development of obesity. Approximately $50 \%$ of the children associated the nutrition with the manifestation of diabetes and hypertension. Their answers are similar to the results reported in our previous study on this problem in schoolchildren at the same age (6). Statistically significant differences were found between the positive answers of boys and girls concerning the relationship "nutrition-diseases" only for diabetes and atherosclerosis $(\mathrm{P}<0,05)$. In both cases predominate the part of girls, who answered correctly (fig.3).

The analysis of the children's answers indicate that more than $60 \%$ of the adolescents have good nutritional knowledge and information about healthy nutrition. Omissions were found in the knowledge about healthy nutrition in $36 \%$ of the children. Statistical evaluation of the relationship between the frequency of overweight and obesity in adolescents and their nutritional knowledge showed that the association was statistically significant $(\mathrm{RR}=2,310$; 95\% CI 1,450-3,681), $\chi^{2}=8,867 ; \mathrm{P}=0,044$.

\section{CONCLUSION}

Recommendations about elaboration of adequate educational programs for nutrition in the schools were made. The 
participation of families, schools, the food and entertainment industries and governmental agencies is necessary for the success of the prevention strategies. The aim is a development of healthy nutritional behavior and eating pattern in adolescents and to reduce the prevalence of overweight and obesity in the schoolchildren.

\section{REFERENCES}

1. Ангелова, К, В.Дулева, С.Петрова, Д.Байкова и др. Национално проучване на хранителния прием и хранителния статус на населението в България., 1997. Антропометричен хранителен статус на населението в България. Хигиена и здрав, XLIII, 2000, № 1,46-47.

2. Байкова, Д. Затльстяването в детската възраст. Практическа педиатрия, 2003, №1, 2-3.

3. Бояджиева, П. Насоки за профилактика на затльстяването и свързаните с него заболявания в юношеска възраст. Хиг. и здрав., 38,1995, №3, 34-35.

4. Ватралова, К, С.Петрова, К.Ангелова, Л.Иванова и др. Национално проучване на храненето и хранителния статус на населението в България, 1998. Антропометричен хранителен статус. Хиг. и здрав., XLIII, 2000,3-4,51-55.

5. Гацева,П. Здравен статус на деца и подрастващи в Пловдивска област за периода 1998-2001г.Scripta Periodica,6, 2003, № 3,16-22.

6. Гацева,П. Честота на свръхтегло и затльстяване при подрастващи и оценка на знанията им по здравословно хранене.-Scripta Periodica, 10,2007, №1,39-48.

7. Дулева,В. Знания по здравословно хранене на ученици от средни общообразователни училища в София.-Scripta Periodica, 8,2005, №2,32-40.

8. Йотова, В., В.Цанева, К.Петрова. Дефиниране на затлъстяването на български деца от началното училище. VII. межд.симпозиум по затльстяване и съпътстващи заболявания, 30.05-1.06.2004,Албена, сб.рез.80-81.

9. Петрова, К. Съвременни тенденции във физическото развитие и честотата на затльстяване на ученици от горна училищна възраст от гр.Варна. - Хиг. и здрав.,1997,1,33-36.

10. Calderon,K.S., C.B.Yucha,S.D. Schaffer. Obesity-related cardiovascular risk factors: intervention recommendations to decrease adolescent obesity.- J Pediatr Nurs. 20,2005,No1,3-14.

11. Cole ,T.J., M.C.Bellzzi, K.M.Flegal, W.H.Dietz. Establishing a standard definition for child overweight an worldwide: international survey.-British Medical Journal,320, 2000,1-6.

12. De Onis, M, AW Onyango, E. Borghi, A. Siyam et al. Development of a WHO growth reference for school-aged children and adolescents. Bulletin of the World Health Organization, 85, 200, 660-667.

13. Graf, C, S.Dordel, W.Tokarski,H.G. Predel. Overweight and obesity in childhood and adolescence. Is prevention possible?- Herz. 31, No6,507-13.

14. Harrell, J.S,A. Jessup, N. Greene. Changing our future: obesity and the metabolic syndrome in children and adolescents. -J Cardiovasc Nurs, 21, 2006 No 4,322-30.

15. ILSI Europe Report Series.Overweight and obesity in European children and adolescents.-ILSI Europe, 2000,10-11.

16. Maes, L. Health behavior and nutrition among school-age children.In:The European Forum on Eating at School-Making Healthy Choices. Strasbourg,Council of Europe,2003,45-51.

17. Simm, P.J., G.A.Werther. Child and adolescent growth disorders- an overview.- Aust Fam Physician, 34, 2005, № 9,731-7.

18. WHO. Diet, nutrition and the prevention of chronic diseases. Tech.Report Ser, 916,WHO,Geneva, 2003.

19. WHO. Obesity: preventing and managing the global epidemic. Report of a WHO consultation on obesity. WHO,Geneva, 1998.

20. WHO. Physical status. The use and interpretation of Anthropometry. Report of WHO Expert Committee.WHO, Technical Report Series 854, WHO, Geneva,1995. 